\title{
Intimate partner violence and severe maternal morbidity among pregnant and postpartum women in São Paulo, Brazil
}

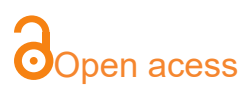

${ }^{1}$ Curso de Enfermagem, Faculdade de Medicina do ABC (FMABC) Santo André (SP), Brasil

2Programa Interunidades de Doutoramento em Enfermagem Universidade de São Paulo (USP) São Paulo (SP), Brasil.

${ }^{3}$ Departamento de Enfermagem Materno-Infantil e Saúde Pública da Escola de Enfermagem de Ribeirão Preto. Universidade de São Paulo (USP) - Ribeirão Preto (SP), Brasil.

${ }^{4}$ Faculdade de Medicina de Ribeirão Preto, Universidade de São Paulo (USP) - Ribeirão Preto (SP), Brasil.

\section{Corresponding author:} maria.puccia@fmabc.br

Manuscript received: January 2018 Manuscript accepted: April 2018

Version of record online: June 2018

\author{
Maria Inês Rosselli Puccia ${ }^{1,2}$, Marli Villela Mamede ${ }^{3}$, Luiz de \\ Souza ${ }^{4}$
}

Keywords: intimate partner violence, battered women, severe acute maternal morbidity, pregnancy complications, maternal health.

\begin{abstract}
This article investigates the association between intimate partner violence (IPV) during a current pregnancy and severe maternal morbidity severe maternal morbidity among pregnant and postpartum women cared for in public maternity centers located in São Paulo, Brazil. A total of 109 women who developed Severe maternal morbidity were selected according to criteria adopted by the World Health Organization (WHO). Another 337 women who did not experience any clinical, laboratory or management intercurrences during a current pregnancy and postpartum were selected for the control group. The participants were submitted to a retrospective investigation of IPV using an instrument adapted from the WHO Multi-country Study on Women's Health and Domestic Violence against Women, applied between November 2010 and June 2011. The relationship between the response variable severe maternal morbidity and the exposure variable (IPV) adjusted for the remaining independent variables was assessed through proportions, a chisquare test, a Fisher's exact test, and multiple logistic regression. A prevalence of $12.6 \%$ (Cl:9.5-15.7) for psychological violence, $7.6 \%$ (Cl:5.1-10.1) for physical violence and 1.6\% (Cl:0.4-2.8) for sexual violence were observed during a current pregnancy in both the case and control groups. Although no statistical significance was found between IPV exposure during a current pregnancy and the occurrence of Severe maternal morbidity $(p>0.264)$, we identified factors associated with unfavorable socio-demographic and reproductive conditions in both the women exposed to IPV and those who developed Severe maternal morbidity. Systematic monitoring of Severe maternal morbidity and routine screening of IPV among pregnant women are important measures to reduce maternal morbidity and mortality and to qualify reproductive health care.
\end{abstract}




\section{INTRODUCION}

Intimate Partner Violence (IPV) is a severe public health problem that is internationally recognized due to its magnitude and the consequences associated with the physical, mental and reproductive health of women, including adverse effects on the health of pregnant women and newborns ${ }^{1}$.

IPV during pregnancy has been associated with a variety of obstetrical risks, including late prenatal care, self-care deficits, abusive use of tobacco, alcohol and other substances, suicide attempts, depression, posttraumatic stress syndrome, sexually transmitted infections, unwanted pregnancies, pregnancy during adolescence, vulvovaginitis, bleeding, miscarriage, urinary tract infections, in addition to deficits in weight gain during pregnancy and violent deaths during pregnancy ${ }^{2-8}$. More severe consequences during pregnancy are described, including placenta previa, uterine rupture, hypertensive disorders, and chorioamnionitis, among others ${ }^{9-13}$.

Severe maternal morbidity and IPV are both important disorders affecting maternal health. There is a consensus in recent studies that IPV poses hazards to the

\section{METHODS}

This case-control study was conducted with 447 women cared for in two public maternity centres in the metropolitan region of São Paulo, Brazil from November 2010 to June 2011.

The study was approved by the Institutional Review Boards of the Faculty of Medicine of ABC and Research Ethics Committee of the City Health Department.

\section{Participants}

Two groups (cases and controls) were selected for the retrospective investigation of IPV in accordance with the study's objective: 1) pregnant or postpartum women who developed severe maternal morbidity and 2) postpartum women who did not experience any clinical intercurrence during the current pregnancy-postpartum period.

An estimated rate of the prevalence of IPV during pregnancy at $10 \%$ was considered to compute the sample size ${ }^{21}$. Hence, in order to detect a minimum difference of $10 \%$ in the proportions of the two populations, a sample of 88 (n) cases with the outcome 'severe maternal morbidity' was obtained in addition to 264(3n) control cases (no complications), with a level of significance of .05 and a power of .80 .

Table 1: Criteria to include cases of severe maternal morbidity (SMM) according to the more frequent markers of potentially life-threatening conditions (PLTC) health of pregnant women. In this context, we ask: Does IPV increase the likelihood of severe maternal morbidity?

Some Brazilian and international studies report that the prevalence of psychological, physical and/or sexual violence during pregnancy ranges from 3.2\% up to $43.1 \%{ }^{11,14}$. High and varying rates of psychological violence during pregnancy were observed, ranging from $16 \%$ to $46.9 \%{ }^{15,16}$, physical violence from $3.6 \%$ to $21 \%{ }^{17,18}$ and sexual violence from $3 \%$ to $9.1 \%{ }^{16,19}$. There are few Brazilian studies addressing IPV among pregnant and postpartum women, but the rates of prevalence of psychological, physical and/or sexual violence range from $6.5 \%$ to $20 \%{ }^{16-21}$.

Based on the hypothesis that IPV increases the chances that severe maternal morbidity will occur, this study's objectives were to evaluate the effect of intimate partner violence (psychological, physical and/or sexual) during the current pregnancy on the outcome 'severe maternal morbidity' and to analyze the factors associated with injuries: IPV and severe maternal morbidity.

We opted to include all cases of severe maternal morbidity during the study period, which totaled 122 cases, among which there were four deaths.

We opted to include a larger number of women in the sample: 122 cases of severe maternal morbidity, among which there were four deaths. There were nine losses among the 118 eligible women due to hospital discharge, premature self-discharge, or transferences. The final sample was composed of 109 cases and 337 controls. Hence, IPV exposure was assessed in a total of 446 women.

\section{Measures}

This study assessed severe maternal morbidity according to the most recent definition provided by the WHO Working Group on Maternal Mortality and Morbidity $^{22}$. The criteria included clinical signs, laboratory tests and clinical management related to conditions more commonly associated with severe obstetrical complications, which define potentially life-threatening conditions (PLTC) during pregnancy, childbirth and postpartum $^{22,23}$.

The criteria proposed are shown in Table 1.

\section{SMM criteria}

SMM criteria Severe Maternal Morbidity

\section{PLTC Markers}

Severe preeclampsia, imminent eclampsia kidney complications, eclampsia, pulmonary edema, acute cyanosis, coagulation disorders, oliguria, septic shock or hypovolemic, jaundice, loss of consciousness for more than de 12 hours, among others. 
Continue- Table 1: Criteria to include cases of severe maternal morbidity (SMM) according to the more frequent markers of potentially life-threatening conditions (PLTC)

\begin{tabular}{|c|c|}
\hline SMM criteria & PLTC Markers \\
\hline $\begin{array}{l}\text { CLINICAL MANAGEMENT } \\
\text { Complexity of Management/interventions }\end{array}$ & $\begin{array}{l}\text { Admission in ICU, emergency hysterectomy } \\
\text { due to infection or bleeding, transfusion } \\
\text { of blood or blood products with dosage of } \\
\mathrm{Hb}<7.0 \mathrm{~g} / \mathrm{dl} \text {, emergency C-section due to } \\
\text { severe maternal morbidity, continuous use } \\
\text { of vasoactive drugs, mechanical ventilation } \\
\text { unrelated to general anesthesia, dialysis, } \\
\text { cardiopulmonary resuscitation, laparotomy, } \\
\text { high complexity cases are transferred } \\
\text { to reference hospitals, hospitalization is } \\
\text { prolonged for more than one week, and } \\
\text { anticonvulsant therapy with magnesium } \\
\text { sulfate } 50 \% \text {. }\end{array}$ \\
\hline $\begin{array}{l}\text { LABORATORY CRITERIA } \\
\text { Evidence of Organ Dysfunction }\end{array}$ & $\begin{array}{l}\text { Significant changes in laboratory parameters: } \\
\text { serum creatinine } \geq 3.5 \mathrm{mg} / \mathrm{dl} \text {; bilirubin }>6.0 \mathrm{mg} / \\
\text { dl; O2 saturation level below } 90 \% \text { for more } \\
\text { than } 60 \text { min.; platelets }<50,000 \text {. Increase } \\
\text { in liver enzymes (AST or TGO, ALT or TGP, } \\
\text { DHL). }\end{array}$ \\
\hline
\end{tabular}

* Adapted from Say et al. [22] and Cecatti et al. [23]

Psychological, physical and/or sexual intimate partner violence during a current pregnancy was defined as interpersonal violence that took place within a relationship with an intimate partner through the intentional use of physical force or power, actual or threatened, of a man against a woman ${ }^{24}$. This variable was investigated according to the severity of the acts committed, based on an instrument standardized by the WHO Multi-country Study on Women's Health and Domestic Violence against Women ${ }^{25}$ and validated in Brazil ${ }^{26}$.

The cases were screened through daily interviews held in the study's hospitals and selected through a structured script used to analyze the medical files according to the adopted eligibility criteria. The interviews were conducted considering the patient's clinical and psycho-emotional conditions, prior to hospital discharge, in a private and appropriate room, ensuring confidentiality with free and informed consent.

Three study controls were selected, through consecutive sampling, in the same week that each case was identified. The control group included all eligible postpartum women, i.e. all those who did not experience clinical, laboratory or management intercurrences during a current pregnancy-postpartum period; who were admitted to either of the two hospitals during the study's time period; and were available to attend the interviews held

\section{RESULTADOS}

The average age among the 446 interviewed women was 26 years old ( $\mathrm{SD}=6.0) ; 48.9 \%$ attended school for 11 or more years, and $43.5 \%$ self-reported being AfroBrazilians or of mixed race. The predominant religion was Catholic (48.2\%), followed by Evangelical Christian (33.2\%); while $79.6 \%$ were either married or had lived consensually with a partner for at least two years. Only $36 \%$ had a paid job, $20.9 \%$ reported being unemployed, under the same conditions adopted for the cases.

Although consecutive sampling does not allow the results to be generalized for the larger population, we chose this procedure because of its applicability in studies conducted in health care services, especially considering the perspective of logistics. The advantages of selecting postpartum women who were rooming-in was also considered because this is a time when they are involved in breastfeeding, newborn care, and visits, and are with companions or under the care of the health staff.

\section{Analytic Methods}

The chi-square test and the Fisher's exact test were used to determine the effect of each independent variable (socio-demographic, sexual, reproductive and partnership characteristics) on each type of violence (psychological, physical and sexual). The procedure was then repeated, this time considering severe maternal morbidity as the dependent variable, and the same independent variables were adjusted for each type of violence (psychological, physical and sexual). In this analysis, the variables that obtained values where $\mathrm{p}<0.250$ were selected to compose the multiple logistic regression model ${ }^{27}$. The level of significance was fixed at 5\%, and the confidence interval at $95 \%$ in all the analyses.

while the remaining participants were characterized as homemakers or students.

In regard to reproductive and sexual health, we observed that the median age at which these women initiated sexual life was 16 years old $($ Min. $=11 /$ Max. $=27$; $\mathrm{P} 25=14 ; \mathrm{P} 75=18)$. Almost half the sample $(48.7 \%)$ reported the use of some contraceptive method before their current pregnancy; oral hormonal contraceptives 
were used by $70.3 \%$ of the women. Note that $23.3 \%$ of the interviewed women reported that their current partner refused to use condoms to prevent pregnancy or sexually transmitted diseases.

A total of $32.1 \%$ of the women were experiencing pregnancy or childbirth for the first time. The average number of live births, including the current birth, was 2.1 children $(\mathrm{SD}=1.4)$. The prevalence of a history of previous miscarriage was $19.7 \%$. We note that 16 women $(3.6 \%$ of the sample) were pregnant, and among the 427 participants, whose outcome was the current birth: $34.9 \%$ (149) were C-sections and 65.1\% (278) were vaginal births, of which $7.2 \%$ (20) were forceps deliveries and 25.9\% (72) were performed without performing an episiotomy.

The estimated prevalence of psychological, physical and sexual violence during the current pregnancy was $12.6 \% \quad(n=56), 7.6 \% \quad(n=34)$ and $1.6 \% \quad(n=7)$, respectively. The estimated prevalence of psychological, physical and/or sexual violence was $12.8 \%(n=57)$.

\section{Psychological Violence}

A significant association was found between psychological violence and marital status: women with no partners were more likely to be subject to violence $(p=0.003)$. The following variables were included in the multiple logistic model: marital status, religion, number of pregnancies, and number of live births prior to the current pregnancy. The following effects were observed on current psychological violence after each independent variable was adjusted to the level of the remaining variables (Table 2): Evangelical religion $(p=0.042)$; no partner $(\mathrm{p}=0.001)$; one prior pregnancy $(\mathrm{p}=0.025)$; and no children $(p<0.074)$, that is, a lower Odds Ratio for psychological violence among those who already had two children (OR=0.1;CI:0-0.6) (Table 2).

Table 2: Multi-Logistic regression model, adjusted odds ratios and corresponding 95\% confidence intervals for psychological violence in current gestation, according to selected variables - Sao Paulo - 2012

\begin{tabular}{|c|c|c|c|c|}
\hline \multirow{2}{*}{$\begin{array}{l}\text { Variable } \\
\text { Religion }\end{array}$} & \multirow[t]{2}{*}{ OR } & \multicolumn{2}{|c|}{ IC (95\%) } & \multirow[t]{2}{*}{ p value* } \\
\hline & & & & \\
\hline Catholic & Reference & & & \\
\hline Evangelical & 2.0 & 1.0 & 3.8 & 0.042 \\
\hline Whithout religion & 0.4 & 0.1 & 3.7 & 0.446 \\
\hline Outher & 1.4 & 0.6 & 3.3 & 0.468 \\
\hline \multicolumn{5}{|l|}{ Marital status } \\
\hline Maried & Reference & & & \\
\hline Has partner (do not live) & 1.5 & 0.6 & 3.9 & 0.406 \\
\hline No partner & 3.6 & 1.7 & 7.7 & 0.001 \\
\hline \multicolumn{5}{|l|}{ Previous pregnancy } \\
\hline 0 & Reference & & & \\
\hline 1 & 3.2 & 1.2 & 8.9 & 0.025 \\
\hline 2 & 2.1 & 0.5 & 9.2 & 0.312 \\
\hline 3 or more & 2.6 & 0.6 & 12.1 & 0.220 \\
\hline \multicolumn{5}{|c|}{ Number of previous living children } \\
\hline 0 & Reference & & & \\
\hline 1 & 0.3 & 0.1 & 1.1 & 0.074 \\
\hline 2 & 0.2 & 0 & 0.6 & 0.010 \\
\hline 3 or more & 0.3 & 0.1 & 1.7 & 0.180 \\
\hline
\end{tabular}

${ }^{*}$ Chi Square Test

\section{Physical Violence}

Statistically, significant results were found for the occurrence of physical violence in relation to occupation, marital status, number of prior pregnancies, and the number of live births prior to the current pregnancy, i.e. physical violence was greater among students and women without a fixed job $(\mathrm{p}=0.021)$, among women without a partner $(p=0.005)$ and with no children $(p=0.018)$. On the other hand, physical violence was less frequent among primiparas $(p=0.020)$.

The multiple logistic regression model revealed the following effects regarding physical violence (Table 3): adolescents (younger than 20 years of age) more frequently experienced physical violence than pregnant women from 20 to 29 years old $(\mathrm{p}=0.016)$; women without a partner also experienced violence more frequently $(\mathrm{p}=0.004)$; women who had at least one previous pregnancy experienced violence more frequently than primiparas $(\mathrm{p}=0.003)$; while physical violence was less frequently observed among women who already had children $(\mathrm{p}<0.042)$ (Table 3$)$.

We note that the differences observed between the simple and multiple regression analyses related to the occurrence of psychological and physical IPV suggest confounding effects associated with the independent variables (socio-demographic, sexual, reproductive and sexual partnership). In the conclusion, however, we considered the results from the multiple logistic regression. 
Table 3: Multi-Logistic regression model, adjusted odds ratios and corresponding 95\% confidence intervals for physical violence in current gestation, according to selected variables - Sao Paulo - 2012

\begin{tabular}{|c|c|c|c|c|}
\hline \multirow{2}{*}{$\begin{array}{l}\text { Variable } \\
\text { Age (years) }\end{array}$} & \multirow[t]{2}{*}{ OR } & \multicolumn{2}{|c|}{ IC (95\%) } & \multirow[t]{2}{*}{ p value* } \\
\hline & & & & \\
\hline $10|---| 19$ & 3.3 & 1.2 & 8.9 & 0.016 \\
\hline $20|---| 29$ & Reference & & & \\
\hline 30 or more & 1.2 & 0.5 & 3.0 & 0.626 \\
\hline \multicolumn{5}{|l|}{ Marital status } \\
\hline Maried & Reference & & & \\
\hline Has parthner (not to live) & 0.6 & 0.1 & 3.0 & 0.569 \\
\hline No parther & 3.7 & 1.5 & 9.1 & 0.004 \\
\hline \multicolumn{5}{|l|}{ Previous pregnancy } \\
\hline 0 & Reference & & & \\
\hline 1 & 8.3 & 2.0 & 33.5 & 0.003 \\
\hline 2 & 3.6 & 0.6 & 23.6 & 0.180 \\
\hline 3 or more & 6.4 & 0.9 & 44.7 & 0.062 \\
\hline \multicolumn{5}{|l|}{ Number of the children previous } \\
\hline 0 & Reference & & & \\
\hline 1 & 0.1 & 0 & 0.6 & 0.009 \\
\hline 2 & 0.1 & 0 & 0.5 & 0.005 \\
\hline 3 ou mais & 0.1 & 0 & 0.9 & 0.042 \\
\hline
\end{tabular}

${ }^{*}$ Chi-square test

Therefore, we observe that the greatest risks for the occurrence of psychological violence during pregnancy were: being an Evangelical Christian, not having a partner, having one prior pregnancy, and having no children. The greatest risks for physical violence include: being younger than 20 years old, not having a partner, having one prior pregnancy and not having children.

\section{Sexual Violence}

Sexual violence was not associated with any of the socio-demographic, sexual or reproductive variables and some characteristics of the affective partnership, possibly due to the low number of women reporting this type of violence (1.6\%).

\section{Severe Maternal Morbidity}

A statistically significant association was found between severe maternal morbidity and the following variables: mother's age $(p<0.001)$, type of childbirth $(p<0.001)$, birth weight $(p<0.001)$, number of live births prior to the current pregnancy $(\mathrm{p}<0.001)$, and prior miscarriage $(\mathrm{p}<0.038)$.

The multiple regression model was adjusted because, in addition to the variables associated with 'severe maternal morbidity', the following variables were also analysed: mother's education $(\mathrm{p}=0.067)$ and duration of relationship $(p=0.200)$. This was because they presented values of $\mathrm{p}<0.250$. The variables that presented effects in this analysis were: being older than 30 years of age $(\mathrm{p}<0.001)$; having had a C-section $(\mathrm{p}<0.001)$; having less than eleven years of schooling $(\mathrm{p}=0.037)$ and not having children $(\mathrm{p}<0.01)$, according to the results described in Table 4. Although low birth weight is a significant risk factor for severe maternal morbidity, it was excluded from the multiple regression analysis because there were few observations (Table 4).

Table 4: Multi-Logistic regression model, adjusted odds ratios and corresponding $95 \%$ confidence intervals for severe maternal morbidity between pregnant women and mothers, according to variables selected - São Paulo, Brazil - 2012

\begin{tabular}{|c|c|c|c|c|}
\hline Variable & OR & Confider & val (95\%) & p value* \\
\hline Age (years) & Reference 20 |---| 29 & & & \\
\hline $10|---| 19$ & 1.9 & 0.9 & 4.0 & 0.113 \\
\hline 30 or older & 3.7 & 2.0 & 6.9 & $<0.001$ \\
\hline \multicolumn{5}{|l|}{ Type of childbirth } \\
\hline Vaginal & Reference & & & \\
\hline C-section & 6.3 & 3.7 & 10.9 & $<0.001$ \\
\hline \multicolumn{5}{|l|}{ Mother's education } \\
\hline Fewer than nine years & Reference & & & \\
\hline
\end{tabular}


Continue- Table 4: Multi-Logistic regression model, adjusted odds ratios and corresponding 95\% confidence intervals for severe maternal morbidity between pregnant women and mothers, according to variables selected - São Paulo, Brazil - 2012

\begin{tabular}{lcccc}
\hline Variable & OR & Confidence Interval (95\%) & p value \\
\hline Incomplete high-school & 2.4 & 1.1 & 4.8 & 0.037 \\
$\quad$ High-school/ more years & 1.3 & 0.6 & 2.7 & 0.487 \\
$\begin{array}{l}\text { Previous Miscarriage } \\
\text { No }\end{array}$ & Reference & & & \\
Yes & 1.7 & 0.9 & 3.2 & 0.086 \\
Number of prior alive births & & & & \\
0 & Reference & & & \\
1 & 0.1 & 0 & 0.6 & 0.011 \\
2 & 0.1 & 0 & 0.3 & 0.001 \\
3 or more & 0.1 & 0 & 0.2 & $<0.001$ \\
\hline
\end{tabular}

${ }^{*}$ Chi-square test

According to the multiple logistic regression analysis of the variable 'severe maternal morbidity', the variables 'psychological and physical violence' are not

Table 5: Distribution of cases of severe maternal morbidity and controls, according to the violence occurring in the current pregnancy, between pregnant women and mothers - Sao Paulo - $2012(n=446)$

\begin{tabular}{lccccccc}
\hline Variable & \multicolumn{2}{c}{ Cases } & \multicolumn{2}{c}{ Control } & \multicolumn{2}{c}{ Total } & p value* $^{*}$ \\
\hline & $\mathrm{n}$ & $\%$ & $\mathrm{n}$ & $\%$ & $\mathrm{n}$ & $\%$ & \\
$\begin{array}{l}\text { Current psychological violence } \\
\quad \text { Yes }\end{array}$ & 15 & 13.8 & 41 & 12.2 & 56 & 12.6 & \\
$\quad$ No & 94 & 86.2 & 296 & 87.8 & 390 & 87.4 & \\
$\quad \begin{array}{l}\text { Current physical violence } \\
\quad \text { Yes }\end{array}$ & 11 & 10.1 & 23 & 6.8 & 34 & 7.6 & \\
$\quad$ No & 98 & 89.9 & 314 & 93.2 & 412 & 92.4 & \\
Current Sexual violence & & & & & & & 0.529 \\
$\quad$ Yes & 1 & 0.9 & 6 & 1.8 & 7 & 1.6 & \\
$\quad$ No & 108 & 99.1 & 331 & 98.2 & 439 & 98.4 & \\
\hline
\end{tabular}

${ }^{*}$ Chi-square test

\section{DISCUSSION}

This study is the first investigation addressing IPV among women who experience severe maternal morbidity based on the WHO's new definition concerning the conditions that potentially threaten maternal life ${ }^{22}$.

The study's findings help to define the profile of women characterized as educated young adults, Caucasian, married or living in consensual union, homemakers, students or unemployed, who initiated sexual activity around the age of 16, with an average of two children. Self-care deficits were observed in terms of regulating fertility and protection against STDs, taking into consideration that most pregnancies occurred due to the non-use of contraceptive methods and the refusal, on the part of the partner, to use condoms.

Although these women present a high educational level, even higher than what is reported in other Brazilian studies $^{28-30}$, it is not sufficient for them to ensure financial autonomy; only $36 \%$ of them reported holding a paid job. This last figure was below what was reported in Brazilian studies addressing IPV among women ${ }^{28-30}$. statistically significant, even after controlling for each of the explanatory variables (Table 5). 
This result is consistent with recent studies reporting IPV prevalence rates (psychological, physical and/or sexual) during pregnancy between $3 \%$ and $57 \% 0^{14,32-35}$.

The prevalence of psychological violence $(12.6 \%$; CI:9.5-15.7) was below that identified in the literature, between $16 \%$ and $46.9 \%{ }^{15,16}$. The same was observed in relation to sexual violence $(1.6 \%$; CI:0,4-2.8), the rates of which ranged from $3 \%$ to $9.1 \%{ }^{16,19}$. The prevalence of physical violence $(7.6 \%$; CI:5.1-10.1) is, however, in agreement with the rates $(3.6 \%$ and $21 \%)$ observed in the recent literature ${ }^{11,17,18,25,32}$.

We observed a greater vulnerability to psychological violence, while sexual violence was the least frequent in this population. Among $57(12.8 \%)$ women from the sample who reported IPV during the current pregnancy, 98.2\% (56) reported psychological violence. Even though psychological violence does not leave visible signs in the way physical violence does, its consequences on maternal health are relevant ${ }^{26}$, and such acts, committed by partners, are often seen as natural aspects of marital relationships.

The factors associated with IPV during pregnancy from the multiple logistic regression model are compatible with the low autonomy of women in coping with violence: evangelical women $(\mathrm{CR}=2,0 ; \mathrm{CI}: 1.0-3.8)$, with no partner $(\mathrm{CR}=3.6$; CI:1.7-7.7), who became pregnant at least once before the current pregnancy $(\mathrm{CR}=3.2$; $\mathrm{CI}: 1.2-8.9)$, have a higher odds of suffering psychological violence. Adolescent pregnant women ( $\mathrm{CR}=3.3$; CI:1.2-8.9), pregnant women with no partner $(\mathrm{CR}=3.7$; IC:1.5-9.1) or who had a previous pregnancy $(\mathrm{CR}=8.3$; IC: $2.0-33.5)$ have more chances of physical violence.

Therefore, the factors associated with the occurrence of IPV during pregnancy identified in this study can be used as risk markers by health professionals, to increase the visibility of the phenomenon of violence in health care services.

The unfavorable characteristics and living conditions of the pregnant women subjected to IPV can be seen from the perspective of gender analysis ${ }^{36-39}$. When deprived of the autonomy to fully exercise their social functions, such as access to education, paid jobs, health services and other public

\section{CONCLUSION}

This study identified that IPV does not increase the likelihood of severe maternal morbidity, but it is the first study to propose an analysis about these events. However, the results show that IPV among pregnant women and severe maternal morbidity represent serious reproductive health problems.

Adolescents, unmarried women who had previously become pregnant were more exposed to intimate partner physical and psychological violence, while evangelical women were twice as likely to be exposed to psychological violence.

Women over 30 years of age with less than nine years of schooling undergoing cesarean delivery were more likely to develop severe maternal morbidity. policies of social support, women in general submit themselves to a hierarchy of male power that is socially and culturally constituted in many societies, and in particular, in countries with low indicators of human and social development ${ }^{1}$.

On the other hand, access to social resources and changes in the attitudes of women, so that they no longer tolerate abuse or control from their partners, can favors reduced rates of violence during pregnancy ${ }^{36,37}$.

This study also identified higher probability of developing severe maternal morbidity among women over 30 years of age $(\mathrm{CR}=3.7, \mathrm{CI}: 2.0-6.9)$, with incomplete secondary education $(\mathrm{CR}=2.4, \mathrm{CI}: 1.1-4.8)$, with a previous history of abortion (CR $=1.7, \mathrm{CI}: 0.9-3.2)$ and whose current delivery was cesarean $(\mathrm{CR}=6.3, \mathrm{CI}$ : 3.7-10.9).

These results support a better understanding of the problem from the perspective of maternal health. IPV and severe maternal morbidity are configured as issues of gender and human rights and should be seen as such in the field of public policies concerning health care $\mathrm{c}^{25,38,40}$.

Both the events imply that there is a need to implement institutional changes to make IPV more visible, as well as to adopt new practices to improve obstetrical care based on continuously monitoring pregnant and postpartum women who develop potentially life-threatening conditions $\mathrm{s}^{1,25,35,38,40}$.

Therefore, we propose routine screening for IPV among pregnant women so that victims of violence are included in network care programmers, e.g. through public health, education, social support, security, and legal services, among other measures ${ }^{1,25,40}$.

The systematic monitoring of severe maternal morbidity through indicators of potentially life-threatening maternal conditions is also suggested as an important strategy to understand their determining factors and to intervene in them in a timely manner. The development of improved care technologies can significantly reduce maternal morbidity ${ }^{38,40-42}$.

Finally, this study's results support a deeper analysis of the phenomena of IPV and severe maternal morbidity as a priority to qualify the integral health care provided to women.

The conclusion is that both pregnant women exposed to IPV and those who experience severe maternal morbidity presented unfavorable socio-demographic and reproductive conditions that increase their vulnerability to worse health conditions, which in turn, reveal that there is difficulty accessing care and a lack of a qualified approach in the health services.

Further studies to investigate the effects of IPV on maternal health are suggested.

\section{Acknowledgments}

Lilia Blima Schraiber who authorized the use of the instrument adapted from the WHO Multi-country Study on Women's Health and Domestic Violence against Women.

\section{REFERENCES}

1. Ellsberg MC. Candies in hell. Research and action on domestic violence against women in Nicaragua. Sweden: Umea University, 2000. 
2. Talley P, Heitkemper M, Chicz-Demet A, Sandman CA. Male violence; stress; and neuroendocrine parameters in pregnancy: a pilot study. Biol Res Nurs. 2006;7(3):222-33. DOI: http://dx.doi.org/10.1177/1099800405283182

3. Miller E, Decker MR, Reed E, Raj A, Hathaway JE, Silverman JG. Male partner pregnancy-promoting behaviors and adolescent partner violence: findings from a qualitative study with adolescent females. Ambul Pediatr. 2007; 7(5):360-6. DOI: http://dx.doi.org/10.1016/j.ambp.2007.05.007

4. Bailey BA, Daugherty RA. Intimate partner violence during pregnancy: incidence and associated health behaviors in a rural population. Mater Child Health J. 2007;11(5):495-503. DOI: http://dx.doi.org/10.1007/s10995-007-0191-6

5. Silverman JG, Gupta J, Decker MR, Kapur N, Raj A. Intimate partner violence and unwanted pregnancy; miscarriage; induced abortion; and stillbirth among a national sample of Bangladeshi women. BJOG. 2007;114(10):1246-52. DOI: http://dx.doi.org/10.1111/j.1471-0528.2007.01481.x

6. Small MJ, Gupta J, Frederic R, Joseph G, Theodore M, Kershaw T. Intimate partner and nonpartner violence against pregnant women in rural Haiti. Int J Gynaecol Obstet. 2008;102(3):226-31. DOI: https://dx.doi.org/10.1016/j.ijgo.2008.05.008

7. Sharps PW, Campbell J, Baty ML, Walker KS, Bair-Merritt MH. Current evidence on perinatal home visiting and intimate partner violence. J Obstet Gynecol Neonatal Nurs. 2008;37(4):480-91. DOI: https://dx.doi.org/10.1111/j.1552-6909.2008.00267.x

8. Wang T, Liu Y, Li Z, Liu K, Xu Y, Shi W, et al. Prevalence of intimate partner violence (IPV) during pregnancy in China: a systematic review and meta-analysis. PLoS One. 2017;12(10):e0175108. DOI: https://dx.doi.org/10.1371/journal.pone.0175108

9. Sharps PW, Laughon K, Giangrande SK. Intimate partner violence and the childbearing year: maternal and infant health consequences. Trauma Violence Abuse, 2007;8(2):105-16. DOI: https://dx.doi.org/10.1177/1524838007302594

10. Silverman JG, Decker MR, Reed E, Raj A. Intimate partner violence victimization prior to and during pregnancy among women residing in 26 U.S. states: Association with maternal and neonatal health. Am J Obstet Gynecol. 2006;195(1):140-8. DOI: https://dx.doi.org/10.1016/j.ajog.2005.12.052

11. Sanchez SE, Qiu C, Perales MT, Lam N, Garcia P, Williams MA. Intimate partner violence (IPV) and preeclampsia among Peruvian women. Eur J Obstet Gynecol Reprod Biol. 2008;137(1):50-5. DOI: http://dx.doi.org/10.1016/j.ejogrb.2007.05.013

12. Leone JM, Lane SD, Koumans EH, DeMott K, Wojtowycz MA, Jensen J, et al. Effects of intimate partner violence on pregnancy trauma and placental abruption. J Womens Health. 2010;19(8):1501-9. DOI: https://dx.doi.org/10.1089/jwh.2009.1716

13. Audi CA, Segall-Corrêa AM, Santiago SM, Andrade MG, Pèrez-Escamila R. Violence against pregnant women: prevalence and associated factors. Rev Saude Pública. 2008;42(5):877-85. DOI: http://dx.doi.org/10.1590/S0034-89102008005000041

14. Kim H, Cain R, Viner-Brown S. Intimate partner violence before or during pregnancy in Rhode Island. Med Health R I. 2010;93(1):29-31.

15. Coonrod DV, Bay RC, Mills TE, Gamble SL. Asymptomatic bacteriuria and intimate partner violence in pregnant women. Am J Obstet Gynecol. 2007;196(6):581.e1-4. DOI: http://dx.doi.org/10.1016/j.ajog.2007.03.018

16. Johri M, Morales RE, Boivin JF, Samayoa BE, Hoch JS, Grazioso CF, et al. Increased risk of miscarriage among women experiencing physical or sexual intimate partner violence during pregnancy in Guatemala City, Guatemala: cross-sectional study. BMC Pregnancy and Childbirth. 2011;11:49. DOI: http://dx.doi.org/10.1186/1471-2393-11-49

17. Chu SY, Goodwin MM, D'Angelo DV. Physical violence against U. S. women around the time of pregnancy, 2004-2007. Am J Prev Med. 2010;38(3):317-22. DOI: http://dx.doi.org/10.1016/j. amepre.2009.11.013

18. Perales MT, Cripe SM, Lam N, Sanchez SE, Sanchez E, Williams MA. Prevalence, types, and pattern of intimate partner violence among pregnant women in Lima, Peru. Violence Against Women. 2009;15(2):224-50. DOI: http://dx.doi.org/10.1177/1077801208329387

19. Chan KL, Brownridge DA, Tiwari A, Fong DY, Leung WC, Ho PC. Associating pregnancy with partner violence against Chinese women. J Interpers Violence. 2011;26(7):1478-500. DOI: http://dx.doi.org/10.1177/0886260510369134

20. Durand JG, Schraiber LB. Violence during pregnancy among public health care users in the Greater São Paulo area: prevalence and associated factors. Rev Bras Epidemiol. 2007;10(3):310-22. DOI: http://dx.doi.org/10.1590/S1415-790X2007000300003 
21. Menezes TC, Amorim MMR, Santos LC, Faúndes A. Domestic Physical Violence and Pregnancy:Results of a Survey in the Postpartum Period. Rev Bras Ginecol Obstet. 2003;25(5):309-16. DOI: http://dx.doi.org/10.1590/S0100-72032003000500002

22. Say L, Souza JP, Pattinson RC; WHO working group on Maternal Mortality and Morbidity classifications. Maternal near miss - towards a standard tool for monitoring quality of maternal health care. Best Pract Res Clin Obstet Gynaecol. 2009;23(3):287-96. DOI: https://dx.doi.org/10.1016/j.bpobgyn.2009.01.007

23. Cecatti JG, Souza JP, Oliveira Neto AF, Parpinelli MA, Sousa MH, Say L, et al. Pre-validation of the WHO organ dysfunction based criteria for identification of maternal near miss. Reprod Health. 2011;8:22. DOI: https://dx.doi.org/10.1186/1742-4755-8-22

24. Krug EG, Mercy JA, Dahlberg LL, Zwi AB. The world report on violence and health. Lancet. 2002;360(9339):1083-8. DOI: https://dx.doi.org/10.1016/S0140-6736(02)11133-0

25. Garcia-Moreno C, Jansen HA, Ellsberg M, Watts CH; WHO Multi-country Study on Women's Health and Domestic Violence against Women Study Team. Prevalence of intimate partner violence: findings from the WHO multi-country study on women's health and domestic violence. Lancet. 2006;368(9543): 12609. DOI: http://dx.doi.org/10.1016/S0140-6736(06)69523-8

26. Ludermir AB, Schraiber LB, D'Oliveira AF, França-Junior I, Jansen HA. Violence against women by their intimate partner and common mental disorders. Soc Sci Med. 2008;66(4):1008-18. DOI: https://dx.doi.org/10.1016/j.socscimed.2007.10.021

27. Hosmer DW, Lemeshow S. Applied logistic regression. New York: John Wiley \& Sons, 2000.

28. Marinheiro ALV, Vieira EM, Souza L. Prevalence of violence against women users of health services. Rev Saude Publica. 2006;40(4):604-10. DOI: http://dx.doi.org/10.1590/S0034-89102006000500008

29. Schraiber LB, D'Oliveira AFPL, Couto MT, Hanada H, Kiss LB, Durand JG, et al. Violence against women attending public health services in the metropolitan area of São Paulo, Brazil. Rev Saude Publica. 2007;41(3);359-67. DOI: http://dx.doi.org/10.1590/S0034-89102007000300006

30. Silva EP, Ludermir AB, Araújo TVB, Valongueiro SA. Frequency and pattern of intimate partner violence before, during and after pregnancy. Rev Saude Publica. 2011;45(6):1044-53. DOI: http://dx.doi.org/10.1590/S0034-89102011005000074

31. D'Oliveira AFPL, Schraiber LB, França-Junior I, Ludermir AB, Portella AP, Diniz CS, et al. Factors associated with intimate partner violence against Brazilian women. Rev Saude Publica. 2009;43(2):299311. DOI: http://dx.doi.org/10.1590/S0034-89102009005000013

32. Taillieu TL, Brownridge DA. Violence against pregnant women: Prevalence, patterns, risk factors, theories, and directions for future research. Aggression Violent Behavior. 2010;15(1):14-35. DOI: https://dx.doi.org/10.1016/j.avb.2009.07.013

33. Costa DCS, Ribeiro MRC, Batista RFL, Valente CM, Ribeiro JVF, Almeida LA, et al. Factors associated with physical violence against pregnant women from São Luís, Maranhão State, Brazil: an approach using structural equation modeling. Cad Saúde Pública. 2017;33(1):e00078515. DOI: http://dx.doi.org/10.1590/0102-311x00078515

34. Shamu S, Abrahams N, Temmerman M, Musekiwa A, Zarowsky C. A systematic review of African studies on intimate partner violence against pregnant women: prevalence and risk factors. PLoS One. 2011;6(3):e17591. DOI: https://dx.doi.org/10.1371/journal.pone.0017591

35. Han A, Stewart DE. Maternal and fetal outcomes of intimate partner violence associated with pregnancy in the Latin American and Caribbean region. Int J Gynaecol Obstet. 2014;124(1):6-11. DOI: https://dx.doi.org/10.1016/j.ijgo.2013.06.037

36. Mendoza MEF, Hernández GM, Zárate MLP, Becerra TL. Violencia de género, embarazo y autoestima en un área urbana de la ciudad de México. Rev Enferm Herediana. 2008;1(1):40-7.

37. Salazar M, Valladares E, Ohman A, Högberg U. Ending Intimate Partner Violence after pregnancy: Findings from a community-based longitudinal study in Nicaragua. BMC Public Health. 2009;9:350. DOI: https://dx.doi.org/10.1186/1471-2458-9-350

38. Silverman JG, Balaiah D, Ritter J, Dasgupta A, Boyce SC, Decker MR, et al. Maternal morbidity associated with violence and maltreatment from husbands and in-laws: findings from Indian slum communities. Reprod Health. 2016;13(1):109. DOI: https://dx. doi.org/10.1186/s12978-016-0223-z

39. Lucena KDT, Deininger LSC, Coelho HFC, Monteiro ACC, Vianna RPT, Nascimento JA. Analysis of the cycle of domestic violence against Women. J Hum Growth Dev. 2016;26(2):139-46. DOI: http://dx.doi.org/10.7322/jhgd.119238

40. Quintanilla BPA, Taft A, McDonald S, Pollock W, Roque Henriquez JC. Social determinants and maternal exposure to intimate partner violence of obstetric patients with severe maternal 
morbidity in the intensive care unit: a systematic review protocol. BMJ Open. 2016;6(11):e013270. DOI: https://dx.doi.org/10.1136/bmjopen-2016-013270

41. Serruya SJ, Mucio B, Martinez G, Mainero L, Francisco A, Say L, et al. Exploring the Concept of Degrees of Maternal Morbidity as a Tool for Surveillance of Maternal Health in Latin American and Caribbean Settings. BioMed Res Int. 2017;2017. DOI: https://dx.doi.org/10.1155/2017/8271042

42. Haddad SM, Cecatti JG, Souza JP, Sousa MH, Parpinelli MA, Costa ML, et al. Applying the maternal near miss approach for the evaluation of quality of obstetric care: a worked example from a Multicenter Surveillance Study. Biomed Res Int. 2014;2014. DOI: http://dx.doi.org/10.1155/2014/989815

\section{Resumo}

Este artigo investigou a associação entre violência por parceiro íntimo (IPV) durante a gravidez atual e morbidade materna grave entre gestantes e puérperas atendidas em maternidades públicas na Grande São Paulo, Brasil. Um total de 109 mulheres que desenvolveram Morbidade materna grave foi selecionado de acordo com os critérios adotados pela Organização Mundial da Saúde (OMS). Outras 337 mulheres que não apresentaram nenhuma intercorrência clínica, laboratorial ou de manejo durante a gestação atual e puerpério, foram selecionadas para o grupo controle. As participantes foram submetidas à investigação retrospectiva de IPV utilizando-se um instrumento adaptado do WHO Multicountry Study on Women's Health and Domestic Violence against Women, aplicado entre Novembro 2010 e Junho 2011. A relação entre a variável resposta (Morbidade materna grave) e a variável exposição (IPV) ajustadas para as demais variáveis independentes, foram avaliadas através de proporções, teste chi-quadrado, teste exato de Fischer e regressão logística múltipla. A prevalência de 12.6\% (IC:9,5$15,7)$ para violência psicológica, $7.6 \%$ (IC:5,1-10,1) para violência física e 1.6\% (IC:0,4-2,8) para violência sexual foi observada durante a gravidez atual em ambos os grupos de casos e controles. Embora não tenha sido identificada significância estatística entre exposição a IPV durante a gravidez atual e ocorrência de Morbidade materna grave $(p>0,264)$, foram verificados fatores associados com condições sociodemográficas e reprodutivas desfavoráveis entre as mulheres expostas a IPV e entre aquelas que desenvolveram Morbidade materna grave. O monitoramento sistemático da Morbidade materna grave e o rastreamento rotineiro para IPV entre gestantes são importantes medidas para reduzir a morbimortalidade materna e para qualificar os serviços de atenção à saúde reprodutiva.

Palavras-chave: violência por parceiro íntimo, mulheres maltratadas, morbidade materna grave, complicações na gravidez, saúde materna.

๑ The authors (2018), this article is distributed under the terms of the Creative Commons Attribution 4.0 International License (http:// creativecommons.org/licenses/by/4.0/), which permits unrestricted use, distribution, and reproduction in any medium, provided you give appropriate credit to the original author(s) and the source, provide a link to the Creative Commons license, and indicate if changes were made. The Creative Commons Public Domain Dedication waiver (http://creativecommons.org/publicdomain/zero/ $1.0 /)$ applies to the data made available in this article, unless otherwise stated. 